\title{
RESEARCH PAPER \\ Effects of saponin-rich quinoa (Chenopodium quinoa Willd.) bran and bran extract in diets of adapted and non-adapted quinoa pests in laboratory bioassays
}

\author{
Nathaniel B. McCartney ${ }^{1}$, M. Isabel Ahumada ${ }^{1}$, Marcela P. Muñoz, I.
}

Marlene Rosales ${ }^{1}$, Angélica M. Fierro ${ }^{2}$, and Rodrigo A. Chorbadjian ${ }^{1}$

'Pontificia Universidad Católica de Chile, Facultad de Agronomía e Ingeniería Forestal, Departamento de Ciencias Vegetales. Av. Vicuña Mackenna 4860, Santiago, Chile.

${ }^{2}$ Pontificia Universidad Católica de Chile, Facultad de Química y de Farmacia, Departamento de Química Orgánica. Av. Vicuña Mackenna 4860, Santiago, Chile.

\begin{abstract}
N.B. McCartney, M.I. Ahumada, M.P. Muñoz, I.M. Rosales, A.M. Fierro, and R.A. Chorbadjian. Effects of saponin-rich quinoa (Chenopodium quinoa Willd.) bran and bran extract in diets of adapted and non-adapted quinoa pests in laboratory bioassays. Cien. Inv. Agr. 46(2): 125-136. Quinoa (Chenopodium quinoa Willd.) produces bitter-tasting triterpene saponins that must be removed prior to consumption, significantly adding to production costs. Breeders have therefore prioritized the development of low-saponin "sweet" cultivars with little concern for the ecological benefits these compounds may confer. Quinoa saponins are thought to provide protection against herbivores and microbial pathogens, although there is very little data to support these assumptions. Here we begin to address the question of whether biologically relevant concentrations of saponins exert negative effects against insects and pathogens that attack quinoa, as well as against species not associated with quinoa. Using bran of the coastal genotype Cáhuil as the source of saponins, we conducted feeding assays with larvae of 3 noctuid insect species. Antifungal activity against 8 species was assayed using bran extract incorporated into PDA media. Quinoa bran showed insecticidal activity against only the non-quinoa feeder Pseudaletia impuncta, while the quinoa feeders Trichoplusia ni and Feltia subterranea were not affected. The bran extract inhibited fungal colony growth of Alternaria arborescens, Botrytis cinerea, and Phytophthora cinnamomi by approximately $50 \%$ but had less growth inhibitory effect on Fusarium oxysporum f. sp. cepae, Pestalotiopsis clavispora, Penicillium digitatum, Geotrichum sp., and the quinoa pathogen Phoma sp. The relatively higher inhibitory activity against some pathogen species did not necessarily correlate with their expected pathogenicity against quinoa. The results of this study suggest that, while the quinoa saponins present in bran and bran extracts may provide some protection against certain insects and phytopathogens, species-specific responses need further exploration.
\end{abstract}

Keywords: Antifungal, fungus, herbivory, insect, noctuidae, oomycete.

Received Apr 30, 2019. Accepted Jun 12, 2019

Corresponding author: rchorba@uc.cl 


\section{Introduction}

Chenopodium quinoa Willd. is a crop plant from the Amaranthaceae family that has been domesticated and widely cultivated throughout the Andean region of South America since the pre-Columbian era. In recent decades, global interest in quinoa has grown due to its unique nutritive properties and extraordinary tolerance to adverse environmental conditions, including cold temperatures, drought, soil salinity, and high altitudes. However, quinoa produces bitter-tasting triterpene saponins that must be removed prior to consumption. As these compounds are localized to the pericarp (Jarvis et al., 2017) and are water soluble, they can be partially removed by washing with water. Alternatively, mechanical dehulling may be used to debitter the seeds by abrasion of the pericarp (Reichert et al., 1986), which has the advantages of reducing water usage and producing as a byproduct a dry powder at a rate of 3 to $8 \%$ by weight (Lozano et al., 2012). This byproduct, referred to as bran or "mojuelo" (Flores et al., 2005), is increasingly utilized by industry for its saponin content, which may be between 17 and 35\% (San Martin et al., 2008; Lozano et al., 2012).

Saponins are a diverse class of soap-like amphipathic glycosides of triterpenoids and steroids produced by a wide variety of plants (Sparg et al., 2004; Faizal and Geelen, 2013). Quinoa saponins comprise a large group of triterpene glycosides that are derivatives of at least seven aglycones, also called sapogenins, including oleanolic acid, hederagenin, phytolaccagenic acid, serjanic acid, $3 \beta$-hydroxy-23-oxo-olean-12-en-28-oic acid, $3 \beta$-hydroxy-27-oxo-olean-12-en-28-oic acid, and 33,23,30-trihydroxy olean-12-en-28-oic acid (Kuljanabhagavad et al., 2008). These oleananetype carbon skeletons are coupled to one or more carbohydrate chains that each consist of up to 3 units of arabinose, galactose, glucose, glucuronic acid, or xylose, giving rise to the 87 unique saponins that have thus far been identified from quinoa (Madl et al., 2006; Kuljanabhagavad and Wink, 2009).
Quinoa saponins are commonly thought to perform roles in defense against seed losses due to bird feeding (Risi and Galwey, 1991; FAO and CIRAD, 2015) and against insect herbivores (Mizui et al., 1990; FAO and CIRAD, 2015), although the evidence supporting these hypotheses is largely anecdotal. In fact, we know of no examples from the literature demonstrating a protective effect of quinoa saponins against insect feeding. One field study even suggests that high saponin content does not protect quinoa plants from some non-Lepidopteran insects (Yábar et al., 2002). In other, more extensively studied plant species, saponins frequently exhibit bioactivity against insect herbivores (De Geyter et al., 2007; Chaieb, 2010; Singh and Kaur, 2018). For example, alfalfa triterpene saponins structurally similar to those of quinoa are effective against the feeding of insects such as pea aphids (Sylwia et al., 2006), flea beetles (Nielsen et al., 2010), diamondback moth (Badenes-Perez et al., 2014), armyworms (Adel et al., 2000), and European corn borer (Nozzolillo et al., 1997).

In addition to protecting against herbivory, saponins also frequently exhibit antimicrobial activity (Osbourn, 1996; Sparg et al., 2004). Little is known about the antimicrobial properties of quinoa saponins, particularly with respect to pathogens relevant to agriculture. Seed extracts have shown activities against the bacteria Staphylococcus aureus and Escherichia coli (Miranda et al., 2014) and the pathogenic yeast of humans Candida albicans (Woldemichael and Wink, 2001), and both crude and purified bran extracts reduce mycelial growth of Botrytis cinerea, a necrotrophic fungus affecting various horticultural crops (Stuardo and San Martin, 2008). Quinoa bran extracts are active ingredients in a commercial fungicide treatment, Heads Up ${ }^{\circledR}$ Plant Protectant (Dutcheshen, 2004; Al-Mughrabi et al., 2010), as well as in a patented fungus-inhibiting and plant growth-stimulating formulation (Bengtsson et al., 2007). Although both treatments may be effective against a variety of phytopathogenic diseases, the manufacturers suggest that they function as elicitors of plant 
resistance, not as fungicides. Consequently, the degree to which quinoa saponins may act directly as antifungals against common phytopathogens and whether concentrations in quinoa seeds are sufficient to provide protection against these pathogens remain unclear.

Here we begin to address the question of whether saponins exert negative effects against both insects and pathogens that attack quinoa, as well as against species not associated with quinoa. We first characterize the sapogenin content of both seeds and bran of the Chilean coastal quinoa genotype Cáhuil by GC-MS and HPLC-UV. Using the observed sapogenin content of Cáhuil seeds as a reference for creating biologically relevant treatments, we then investigate the effects of quinoa bran on the growth and survival of two noctuid moth larvae, Trichoplusia ni (Hübner) and Feltia subterranea (Fabricius), which are reported Lepidopteran pests of quinoa (Cranshaw et al., 1990; Cruces et al., 2016), as well as Pseudaletia impuncta (Guenée), a phytophagous noctuid moth that has not been observed feeding on quinoa crops (Artigas, 1994). To investigate the possible antifungal properties of quinoa saponins, we then quantify the effects of a bran extract on the growth of eight common plant pathogens. Plant pathogen isolates were Phoma sp., Botrytis cinerea, Alternaria arborescens, Phytophthora cinnamomi, Fusarium oxysporum $\mathrm{f}$. sp. cepae, Pestalotiopsis clavispora, Penicillium digitatum, and Geotrichum sp. Among them, Phoma sp. is a common plant fungal pathogen found in soil that causes blight on a variety of plants, including quinoa (Cruces et al., 2016). Botrytis cinerea is an ascomycete necrotic fungus affecting many crop species, with one report of this species infecting quinoa (Risi and Galwey, 1984). Alternaria arborescens is an ascomycete fungal pathogen of plants causing stem canker in tomato; Phytophthora cinnamomi is a soilborne oomycete causing "root rot" or "dieback"; Fusarium oxysporum f. sp. cepae is an ascomycete fungal pathogen causing root and basal rot of onion; Pestalotiopsis clavispora is a fungus responsible for stem end rot in avocado, dieback in blueberry, leaf spot of pecan, and postharvest fruit rot in loquat; Penicillium digitatum is an ascomycete soil fungus responsible for postharvest fruit disease in citrus fruits called green rot or green mold; and Geotrichum is a ubiquitous genus of ascomycete fungi found worldwide in soil, water, air, sewage, plant materials, and dairy products (Latorre, 2018). The underlying hypothesis is that quinoa-adapted pests should be more tolerant to quinoa saponins than non-adapted species.

\section{Materials \& Methods}

\section{Plant material}

Non-debittered seeds and bran of the coastal quinoa genotype Cáhuil were obtained from quinoa farms associated with the agricultural cooperative Cooproquinoa, located in Cáhuil, O'Higgins Region, Chile. Prior to extract preparation, these tissues were ground to a fine powder using a coffee mill and kept dry in a desiccator.

\section{Preparation of saponins and sapogenins for bioassays and standards}

Saponin extract for use in fungal bioassays was prepared from $200 \mathrm{~g}$ of quinoa bran. The tissue was defatted with hexane at room temperature and dried, yielding $192 \mathrm{~g}$. Four $48 \mathrm{~g}$ aliquots were subjected to Soxhlet extraction with $80 \%$ aqueous ethanol for 10 hours, followed by repeated maceration with $80 \%$ aqueous ethanol $\left(20 \mathrm{~mL} \mathrm{~g}^{-1}\right)$ at $60^{\circ} \mathrm{C}$. After removing solids by decanting and vacuum filtration, extract was evaporated to dryness $(86.4 \mathrm{~g})$ and redissolved in $400 \mathrm{~mL}$ of water.

To prepare pure standards, aglycones were generated from $25 \mathrm{~mL}$ of the saponin extract by acid hydrolysis with $2.4 \mathrm{~N} \mathrm{HCl}$ refluxed for 2 hours. A light brown precipitate was collected by vacuum filtration and subjected to silica gel flash chromatography with chloroform-methanol $(24: 1, v / v)$. Fractions were monitored by TLC 
(silica gel $60 \mathrm{~F}_{254}$, Merck, Darmstadt, Germany) using chloroform-methanol $(24: 1, \mathrm{v} / \mathrm{v})$ as a solvent system. Visualization of sapogenins was achieved by spraying TLC plates with Komarowsky reagent (4-hydroxybenzaldehyde-sulfuric acid) and heating them to $100^{\circ} \mathrm{C}$. Hedergenin and phytolaccagenic acid co-eluted in one fraction, and oleanolic acid and serjanic acid co-eluted in a second fraction. The co-eluting pairs were subsequently separated by semi-preparative HPLC using a Dionex UltiMate 3000 equipped with a UV-Vis photodiode array detector and a Restek Ultra $\mathrm{C}_{18}$ $5 \mu \mathrm{m} \times 150 \mathrm{~mm} \times 21.2 \mathrm{~mm}$ column. An isocratic elution method using acetonitrile-methanol (3:2, $\mathrm{v} / \mathrm{v}$ ) pumped at $5 \mathrm{~mL} \mathrm{~min}^{-1}$ and detection at 210 $\mathrm{nm}$ produced clean fractions of four triterpene sapogenins. Sapogenins were further purified by recrystallization from methanol, yielding white crystalline products.

Identification of the sapogenins isolated from quinoa was accomplished by comparison to reference standards of oleanolic acid and hederagenin (Sigma-Aldrich, St. Louis, MO, USA) as well as by GC-MS analysis using a PerkinElmer Clarus 680 gas chromatograph coupled with a PerkinElmer Clarus SQ 8 mass spectrometer and a Zebron ZB-5MS (30 $\mathrm{m} \times 0.25 \mathrm{~mm} \times 0.25$ $\mu \mathrm{m})$ column. The column temperature was programmed with an initial temperature of 70 ${ }^{\circ} \mathrm{C}$, followed by a $2 \mathrm{~min}$ hold time, a ramp of $30{ }^{\circ} \mathrm{C} \min ^{-1}$ to $200{ }^{\circ} \mathrm{C}$, a ramp of $8{ }^{\circ} \mathrm{C} \mathrm{min}^{-1}$ to $300{ }^{\circ} \mathrm{C}$, and a $15 \mathrm{~min}$ hold. Injections of $2 \mu \mathrm{L}$ were made with the inlet in splitless mode at $250{ }^{\circ} \mathrm{C}$ and with a helium carrier gas flow rate of $1.0 \mathrm{~mL} \mathrm{~min}{ }^{-1}$. EI analysis used scans from $\mathrm{m} / \mathrm{z}$ 50-620 amu and default MS settings (ion source: $230{ }^{\circ} \mathrm{C}$, quadrupole: $150{ }^{\circ} \mathrm{C}$, and spectra generation at $70 \mathrm{eV}$ ). Samples were silylated just prior to analysis by incubating them at 50 ${ }^{\circ} \mathrm{C}$ for 20 minutes with $50 \mu \mathrm{L}$ BSTFA containing $1 \%$ TMCS (Sigma-Aldrich) and $50 \mu \mathrm{L}$ dry pyridine. Obtained mass spectra were consistent with published spectra for TMS-oleanolic acid, TMS-hederagenin, TMS-serjanic acid, and TMS-phytolaccagenic acid (Madl et al., 2006;
Gómez-Caravaca et al., 2012; Medina-Meza et al., 2016; Ruiz et al., 2017).

\section{Sapogenin quantification}

Seed tissue was processed by first defatting $75 \mathrm{mg}$ of tissue with $1 \mathrm{~mL}$ of hexane, followed by three 30 min macerations in $1.5 \mathrm{~mL}$ of $80 \%$ aqueous methanol at $60^{\circ} \mathrm{C}$ with 15 minutes of sonication. After evaporating to dryness, extracts were resuspended in $1.5 \mathrm{~mL}$ of water and hydrolyzed with $1.5 \mathrm{~mL}$ of $6 \mathrm{~N} \mathrm{HCl}$ at $95^{\circ} \mathrm{C}$ for two hours. The hydrolysis products were partitioned three times with $2 \mathrm{~mL}$ aliquots of chloroform, and the organic phase was washed with $5 \mathrm{~mL}$ of water to remove remaining acid and dried with anhydrous sodium sulfate. The samples were then evaporated to dryness, and the hydrolysis products resuspended in methanol and stored at $-20{ }^{\circ} \mathrm{C}$.

HPLC of sapogenins was performed using a Dionex UltiMate 3000 equipped with a photodiode array detector. Separations were achieved with a Merck LiChrosorb $250 \mathrm{~mm} \times 4 \mathrm{~mm}$ column packed with $5 \mu \mathrm{m} \mathrm{C}_{18}$ using an isocratic elution method of acetonitrile-water $(9: 1, \mathrm{v} / \mathrm{v})$ pumped at $0.5 \mathrm{~mL} \mathrm{~min} \mathrm{~m}^{-1}$ for $30 \mathrm{~min}$ with detection at 210 $\mathrm{nm}$. External calibration standards prepared with commercial standards as well as purified natural compounds were used to quantify the sapogenins. Mean abundances of aglycone products from seven seed samples and four bran samples were then used as a proxy for saponin abundance when creating physiologically relevant fungal bioassay treatments.

\section{Insect bioassay}

Feltia subterranea and P. impuncta were obtained from the eggs of mated females collected from wild populations in central Chile using a self-made light trap. Trichoplusia ni larvae were from a labreared colony grown on quinoa plants for at least 5 generations. One first instar larva was introduced into each of 15 replicate containers of artificial 
diet prepared with $0,20,40$ or $80 \mathrm{mg}$ of quinoa bran per gram of diet (dry weight), equating to $0,3,6$, and $12 \mathrm{mg}$ of total sapogenins per gram of diet. Artificial diet was modified from Shorey and Hale (1965) by replacing soaked beans with wheat germ, corn flour and defatted milk powder. A supply of fresh diet was provided in excess, and larvae were permitted to feed freely until pupation. Survival was recorded after 6 days, 13 days, and upon pupation. Developmental time was determined as the number of days each larva took to develop from first instar to pupation. Insects were maintained at $20^{\circ} \mathrm{C}$ with a $12 \mathrm{~h}$ light period.

\section{Fungal bioassay}

Eight plant pathogen isolates were assayed: Phoma sp. was isolated from infested quinoa plants by growing infested tissue on PDA media, and its species identity is under investigation. Alternaria arborescens, Botrytis cinerea, Phytophthora cinnamomi, Fusarium oxysporum $\mathrm{f}$. sp. cepae, Pestalotiopsis clavispora, Penicillium digitatum, and Geotrichum sp. were obtained from stock cultures maintained in the lab. All isolates were plated on PDA, and $5 \mathrm{~mm}$ plugs of mycelia were transferred to $90 \mathrm{~mm}$ plates consisting of either PDA only, PDA with benomyl fungicide $\left(0.6 \mathrm{mg} \mathrm{ml}^{-1}\right)$, or PDA with quinoa bran ethanolic $(\mathrm{EtOH})$ extract at concentrations of 65,130 , and $260 \mu \mathrm{ml}^{-1}$. These concentrations of EtOH extracts were calculated to contain the equivalent of 5,10 , and $20 \mathrm{mg} \mathrm{ml}^{-1}$ of sapogenins, respectively. All treatments were replicated in triplicate. Colonies were maintained at $28^{\circ} \mathrm{C}$ and colony radius was monitored daily for 6 days. To quantify treatments effects, colony growth inhibition was calculated as the radial growth of the colony divided by the growth of the fungal species in the control treatment, which were grown on only PDA media.

\section{Statistical analyses}

The insect bioassay utilized a completely randomized design. Each experimental unit was a single container with 1 larva, and treatments consisted of 15 replicates. The fungal bioassay used a completely randomized design with 3 replicates. Differences among treatments were analyzed by one-way ANOVA, and means were separated by Fisher's protected LSD test.

\section{Results}

\section{Sapogenin analysis}

Four of the seven previously described triterpene saponin aglycones were identified in the extracts of Cáhuil seeds and bran, including hederagenin, oleanolic acid, phytolaccagenic acid, and serjanic acid, with oleanolic acid being the most abundant sapogenin observed in this genotype at about $40 \%$ of the total sapogenin mass. Figure 1 depicts a typical GC-MS chromatogram of a derivatized sapogenin

Table 1. Comparative analysis of sapogenin content of Cáhuil seed vs. bran.

\begin{tabular}{lcccc}
\hline & \multicolumn{2}{c}{ Cáhuil Seed } & \multicolumn{2}{c}{ Cáhuil Bran } \\
\hline & $\mathrm{mg} \mathrm{g}^{-1} \pm$ S.E. & $\% \pm$ S.E. & $\mathrm{mg} \mathrm{g}^{-1} \pm$ S.E. & $\% \pm$ S.E. \\
hederagenin & $2.61 \pm 0.03$ & $21.1 \pm 0.2$ & $34.0 \pm 0.9$ & $22.0 \pm 0.2$ \\
oleanolic acid & $4.62 \pm 0.03$ & $37.2 \pm 0.2$ & $66.9 \pm 2.2$ & $43.3 \pm 0.4$ \\
phytolaccagenic acid & $3.99 \pm 0.07$ & $32.2 \pm 0.4$ & $37.1 \pm 1.0$ & $24.0 \pm 0.3$ \\
serjanic acid & $1.18 \pm 0.03$ & $9.5 \pm 0.3$ & $16.5 \pm 0.4$ & $10.7 \pm 0.1$ \\
Total & $12.4 \pm 0.1$ & & $154.5 \pm 4.3$ & \\
\hline
\end{tabular}


sample. Bran and seed extracts displayed similar proportions of these compounds, though the bran yielded higher proportions of oleanolic acid and lower proportions of phytolaccagenic acid than did seed tissue (Table 1). The bran yielded about twelve times more sapogenins by weight than seed tissue (154.5 $\mathrm{mg} \mathrm{g}^{-1}$ versus $12.45 \mathrm{mg} \mathrm{g}^{-1}$ ), making the bran a better choice for preparing the large quantities of saponins required for bioassays. Sapogenin abundances obtained from seed tissue were comparable to those reported in the literature for other "bitter" varieties (Mastebroek et al., 2000; Medina-Meza et al., 2016) and were used to establish biologically relevant saponin treatments for both the fungal and insect bioassays.

\section{Insect bioassay}

Survival and developmental times of the three noctuid species are given in Table 2. Quinoa bran treatments had no effect on the survival or developmental time of quinoa feeder F. subterranea. Survival of the quinoa feeder $T$. $n i$ was not affected, but bran content caused a dose-dependent reduction of developmental time $(\mathrm{p}<0.001)$. Rela- tive to the other two noctuid species, P. impuncta experienced a poor survival rate on the artificial diet (64\% after 6 days, 36\% after 13 days, and $20 \%$ at pupation), and the survival rates under bran treatments were significantly less than that of controls after 6 days $(p<0.001)$ and 13 days $(p<0.008)$, with only one larva surviving to pupation. The poor survival rates of controls interfered with the observance of developmental time differences between $P$. impuncta treatments.

\section{Fungal bioassay}

Bran extract inhibited colony growth of Alternaria arborescens and Botrytis cinerea up to $37.6 \pm 2.1 \%$ at day $6\left(F_{4,10}=95.4, P<0.001\right)$ and $53.6 \pm 1.6 \%$ at day $3\left(F_{4,10}=492.0, P<0.001\right)$, respectively (Fig. 2). Phytophthora cinnamomi exhibited up to $51.5 \pm 2.9 \%\left(F_{4,10}=346.9, P<0.001\right)$ growth inhibition 2 days after inoculation, falling to $0 \%$ by day 4. Bran extract inhibited Fusarium oxysporum 10 to almost $20 \%$, while the remaining fungi experienced only minimal inhibition of less than $10 \%$. Alternaria arborescens and P. cinnamomi growth inhibition occurred in a positive dose

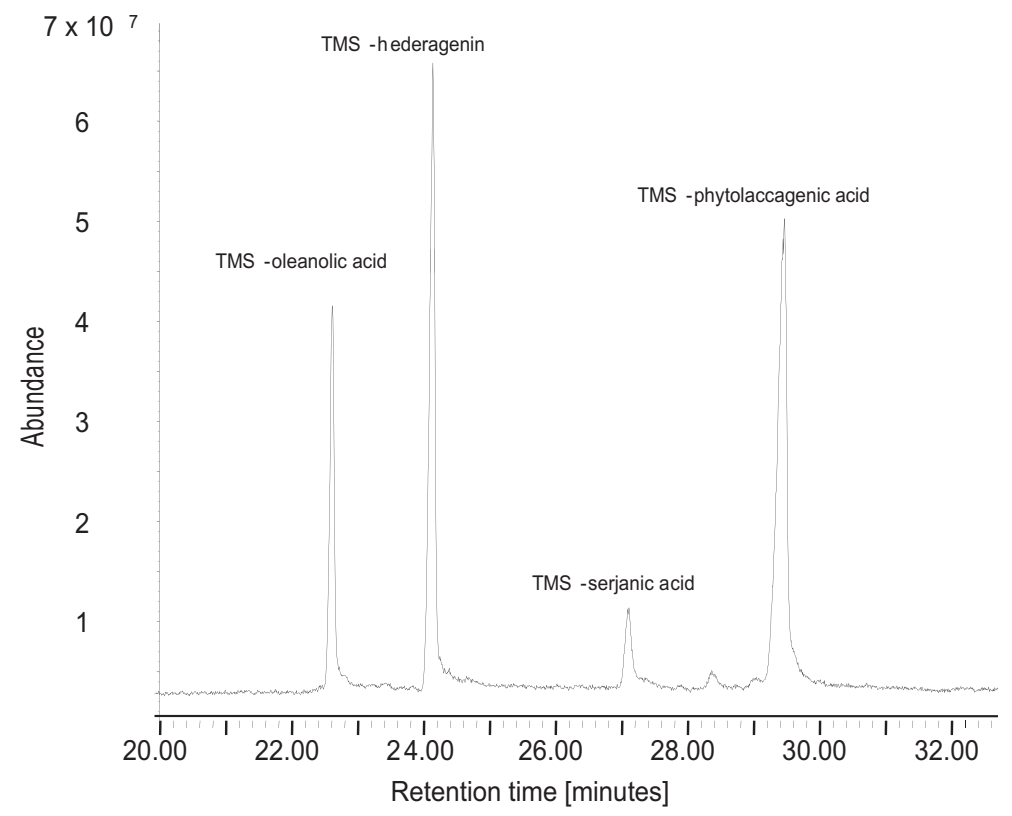

Figure 1. GC-MS chromatogram of trimethylsilylated (TMS) sapogenins derived from a quinoa seed extract. 
Table 2. Survival and developmental time of F. subterranea, T. ni, and P. impuncta when feeding on artificial diet containing varying concentrations of quinoa bran.

\begin{tabular}{|c|c|c|c|c|}
\hline \multirow{2}{*}{$\begin{array}{l}\text { Cáhuil bran in diet } \\
\left(\mathrm{mg} \mathrm{g}^{-1}\right)\end{array}$} & \multicolumn{3}{|c|}{ Survival (\%) } & \multirow{2}{*}{$\begin{array}{c}\text { Developmental time } \\
\text { (No. days } \\
\text { L1 - pupa) }\end{array}$} \\
\hline & 6 Days & 13 Days & L1 - pupa & \\
\hline \multicolumn{5}{|c|}{------------- Feltia subterranea -------------- } \\
\hline 0 & $100.0 \pm 0.0$ & $100.0 \pm 0.0$ & $53.3 \pm 13.3$ & $44.6 \pm 2.3$ \\
\hline 20 & $86.7 \pm 9.1$ & $80.0 \pm 10.7$ & $73.3 \pm 11.8$ & $44.6 \pm 1.6$ \\
\hline 40 & $93.3 \pm 6.7$ & $86.7 \pm 9.1$ & $53.3 \pm 13.3$ & $42.9 \pm 1.2$ \\
\hline 80 & $93.3 \pm 6.7$ & $86.7 \pm 9.1$ & $66.7 \pm 12.6$ & $43.7 \pm 1.5$ \\
\hline$P$-value & 0,561 & 0,396 & 0,610 & 0,874 \\
\hline \multicolumn{5}{|c|}{------------- Trichoplusia ni -------------- } \\
\hline 0 & $100.0 \pm 0.0$ & $93.3 \pm 6.7$ & $93.3 \pm 6.7$ & $22.8 \pm 0.6 \mathrm{a}$ \\
\hline 20 & $100.0 \pm 0.0$ & $100.0 \pm 0.0$ & $100.0 \pm 0.0$ & $20.4 \pm 0.4 \mathrm{~b}$ \\
\hline 40 & $100.0 \pm 0.0$ & $86.7 \pm 9.1$ & $86.7 \pm 9.1$ & $18.7 \pm 0.6 \mathrm{c}$ \\
\hline 80 & $93.3 \pm 6.7$ & $93.3 \pm 6.7$ & $93.3 \pm 6.7$ & $17.5 \pm 0.4 \mathrm{c}$ \\
\hline$P$-value & 0,410 & 0,583 & 0,583 & $<0.001$ \\
\hline \multicolumn{5}{|c|}{ 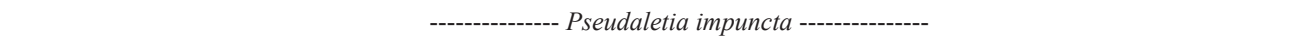 } \\
\hline 0 & $64.3 \pm 13.3 \mathrm{a}$ & $35.7 \pm 13.3 \mathrm{a}$ & $20.0 \pm 10.7$ & $44.0 \pm 1.0$ \\
\hline 20 & $0.0 \pm 0.0 \mathrm{c}$ & $0.0 \pm 0.0 \mathrm{~b}$ & $0.0 \pm 0.0$ & -- \\
\hline 40 & $35.7 \pm 13.3 \mathrm{~b}$ & $28.6 \pm 12.5 \mathrm{a}$ & $6.7 \pm 6.7$ & $43.0^{\dagger}$ \\
\hline 80 & $0.0 \pm 0.0 \mathrm{c}$ & $0.0 \pm 0.0 \mathrm{~b}$ & $0.0 \pm 0.0$ & -- \\
\hline$P$-value & $<0.001$ & 0,008 & 0,094 & 0,667 \\
\hline
\end{tabular}

${ }^{\dagger}$ Only one larva developed into pupa

dependent relationship but no clear relationship was observed in the other species. The fungicide treatment positive control produced a minimum inhibition of $50 \%$ for all species.

\section{Discussion}

The sapogenin profiles of Cáhuil seeds and bran we report here were very similar to each other, although they differ somewhat from the seed profile previously reported by Medina-Meza et al., 2016. While total seed sapogenins were nearly identical (11.0 $\mathrm{mg} \mathrm{g}^{-1}$ vs. $12.4 \mathrm{mg} \mathrm{g}^{-1}$ ), MedinaMeza et al. (2016) found a higher proportion of phytolaccagenic acid (5.91 $\mathrm{mg} \mathrm{g}^{-1}$ vs. $\left.3.99 \mathrm{mg} \mathrm{g}^{-1}\right)$ and lower quantities of oleanolic acid $(2.44 \mathrm{mg}$ $\mathrm{g}^{-1}$ vs. $\left.4.62 \mathrm{mg} \mathrm{g}^{-1}\right)$, hederagenin (1.91 $\mathrm{mg} \mathrm{g}^{-1}$ vs. $\left.2.61 \mathrm{mg} \mathrm{g}^{-1}\right)$, and serjanic acid ( $0.68 \mathrm{mg} \mathrm{g}^{-1}$ vs. 1.18 $\mathrm{mg} \mathrm{g}^{-1}$ ). These discrepancies may be explained by variations among Cáhuil landraces, differences in growth conditions, or the use of different analysis methodologies.

Feeding quinoa bran to the quinoa pests $F$. subterranea and $T$. ni produced no observable negative effects on survival or developmental time, suggesting that the abundances and/or types of saponins produced by Cáhuil plants are not sufficient to provide protection against these adapted species. However, the saponin content may be sufficient to protect against poorly adapted species, which could explain why $P$. impuncta does not feed on this crop. It should be noted that bran powder can contain some nutritive components, as it is typically composed of a variety of tissues, including 


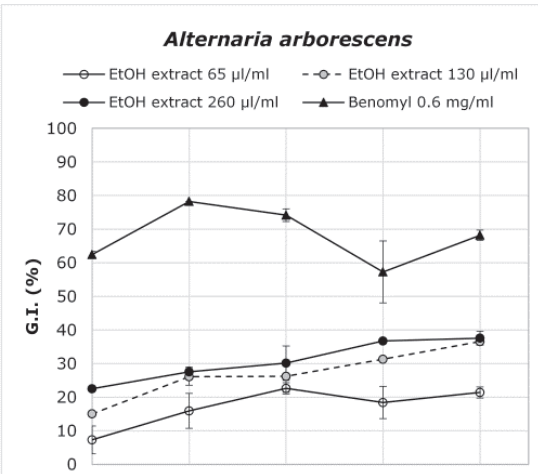

Fusarium oxysporum f. sp. cepae

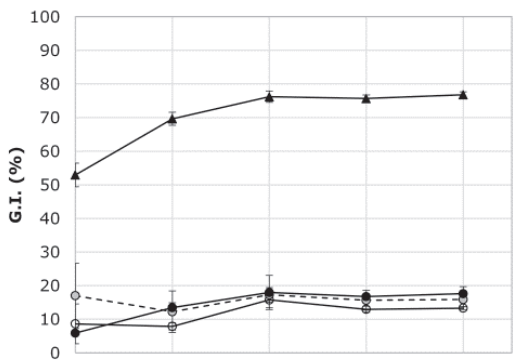

Penicillium digitatum

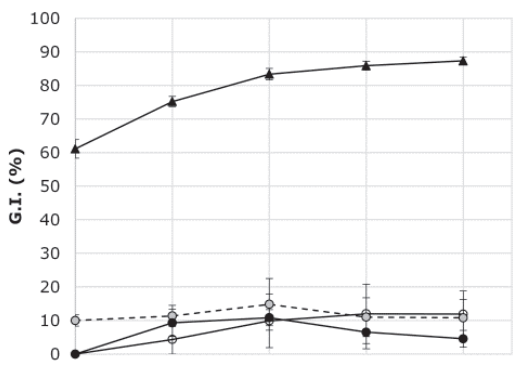

Phoma sp.

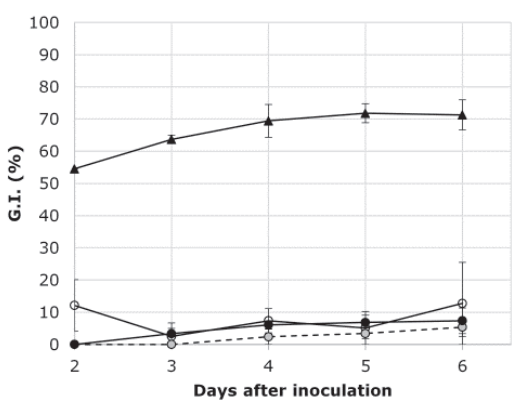

Botrytis cinerea

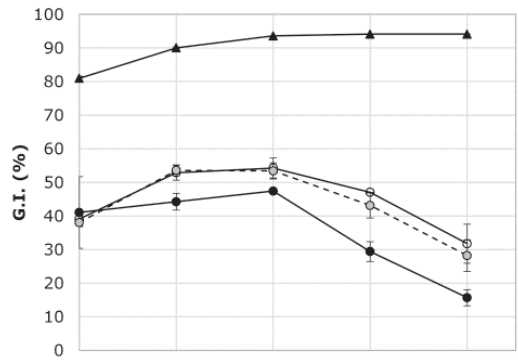

Geotrichum sp.

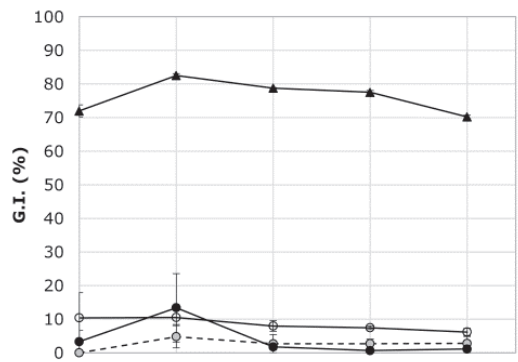

Pestalotiopsis clavispora

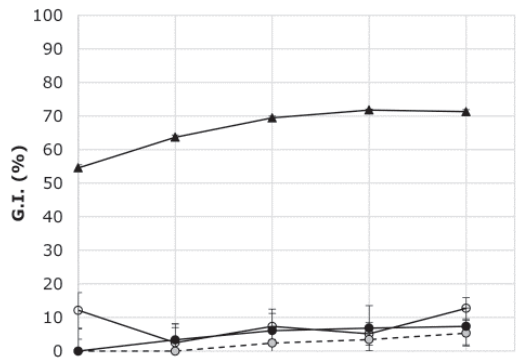

Phytophthora cinnamomi

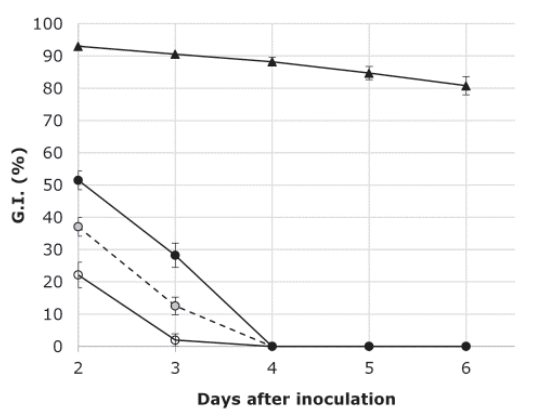

Figure 2. Colony growth inhibition (G. I.) of phytopathogens in PDA media containing bran EtOH extract in the saponin aglycone equivalent concentration of 5,10 , or $20 \mathrm{mg} \mathrm{m}^{-1}$ relative to media containing benomyl fungicide.. 
not only the abraded seed coats but also husks and seed flour due to the process of cleaning and debittering seed crops. For example, bran of Bolivian genotype 'Real' may have $6 \%$ protein by weight (Stuardo and San Martin, 2008). While these nutritive components may have contributed to slightly faster development of $T$. $n i$ feeding on bran, they were not sufficient to confer any advantage to $P$. impuncta.

Incorporating quinoa bran extract into media inhibited the colony growth of all fungal species assayed, although the degree of inhibition varied widely by species, and for some species, by concentration as well. Phoma sp. isolated from infested quinoa plants was less sensitive to the addition of bran extract into the growth media than Botrytis cinerea. Although one study found Botrytis cinerea affected the stems and inflorescences of mature quinoa (Risi and Galwey, 1984), this fungal species does not seem to be as relevant as other species reported by Cruces et al. (2016). Interestingly, our results also show higher inhibitory activity against the soil pathogens $A$. arborescens and Phytophthora cinnamomi, against which the saponin rich seed coat could potentially provide some protection during the earliest stage of plant development. The results of this study suggest that, while the quinoa saponins present in bran and bran extracts may provide some protection against certain insects and fungi, their effects are not widespread. Previous studies that investigated the toxicity of these products to golden apple snails, goldfish, and tilapia (San Martin et al., 2008) as well as to the fungus Botrytis cinerea (Stuardo and San Martin, 2008) concluded that, while quinoa saponins may have minimal to no toxicity in their natural state, conversion of bidesmosidic saponins to monodesmosides by alkaline hydrolysis dramatically increased toxicity. Of the 87 known quinoa saponins, only 6 are monodesmosides (Kuljanabhagavad and Wink, 2009). Consequently, we may expect quinoa saponins to vary in activity depending upon the abundance of monodesmosidic saponins produced by the genotype, as well as by the capability of the target organism to perform partial hydrolysis on bidesmosidic saponins. As our methodology does not permit analysis of specific saponin structure, future studies will be necessary to investigate whether protective qualities of different quinoa genotypes correlate with the relative abundance of monodesmosidic saponins.

\section{Acknowledgements}

We thank financial support provided by Concurso de Investigación Interdisciplinaria II160018. Proyecto financiado por la Vicerrectoría de Investigación de la Pontificia Universidad Católica de Chile, mediante el concurso de Investigación interdisciplinaria 2016. We also thank Francisco Fuentes for providing quinoa bran material, and Jorge Molina for assistance conducting insect feeding experiments.

\section{Resumen}

N.B. McCartney, M.I. Ahumada, M.P. Muñoz, I.M. Rosales, A.M. Fierro, y R.A. Chorbadjian. Efectos del salvado y extracto de salvado de quinua rico en saponina (Chenopodium quinoa Willd.) en dietas de plagas de quinua adaptadas y no adaptadas en bioensayos de laboratorio. Cien.Agr. 46(2): 125-136. La quínoa (Chenopodium quinoa Willd.) produce saponinas triterpénicas de sabor amargo que deben eliminarse antes del consumo, lo que aumenta significativamente los costos de producción. Por lo tanto, los fitomejoradores han priorizado el desarrollo de cultivares "dulces" bajos en saponina con poca consideración por los beneficios ecológicos que estos compuestos pueden conferir. Se cree que las saponinas de quínoa brindan protección contra herbívoros y fitopatógenos microbianos, aunque existen muy pocos datos que respalden estos supuestos. En este estudio comenzamos a abordar la pregunta 
de si concentraciones biológicamente relevantes de saponinas ejercen efectos negativos contra los insectos y patógenos que atacan a la quínoa, así como también contra especies no asociadas con la quínoa. Utilizando el salvado del genotipo costero Cáhuil como fuente de saponinas, realizamos ensayos de alimentación con larvas de 3 especies de insectos lepidópteros de la familia Noctuidae. La actividad antifúngica se ensayó contra 8 especies fitopatogénicas usando extracto de salvado incorporado en medios PDA. El salvado de quinua mostró actividad insecticida solo contra la especie de insecto que no afecta quínoa Pseudaletia impuncta, mientras que los insectos que son plaga de quínoa Trichoplusia ni y Feltia subterranea no se vieron afectados. El extracto de salvado inhibió el crecimiento de colonias de los fitopatógenos Alternaria arborescens, Botrytis cinerea y Phytophthora cinnamomi en aproximadamente un $50 \%$, pero tuvo un menor efecto inhibidor del crecimiento sobre Fusarium oxysporum f. sp. cepae, Pestalotiopsis clavispora, Penicillium digitatum, Geotrichum sp. y el patógeno de la quínoa Phoma sp. La actividad inhibidora relativamente mayor contra algunas especies de patógenos no se correlaciona necesariamente con su patogenicidad esperada contra la quínoa. Los resultados de este estudio sugieren que, si bien las saponinas de quínoa presentes en el salvado y los extractos de salvado pueden proporcionar cierta protección contra ciertos insectos y fitopatógenos, las respuestas específicas de las especies necesitan una mayor exploración.

Palabras clave: Antihongo, herbivoría, hongos, insecto, noctuidae, oomycete.

\section{References}

Adel, M.M., F. Sehnal, and M. Jurzysta. 2000. Effects of alfalfa saponins on the moth Spodoptera littoralis. J. Chem. Ecol. 26:1065-1078. DOI: 10.1023/A:1005445217004.

Al-Mughrabi, K.I., A. Vikram, and R. Poirier. 2010. Effect of saponins of Chenopodium quinoa applied as seed or foliar treatments on dry rot, common scab and black scurf diseases of potato. Am. J. Plant Sci. Biotech. 4(2):65-70.

Artigas, J.N. 1994. Entomología Económica. Ediciones Universidad de Concepción, Concepción, Chile, Vol. II: 943 p.

Badenes-Perez, F.R., J. Gershenzon, and D.G. Heckel. 2014. Insect attraction versus plant defense: young leaves high in glucosinolates stimulate oviposition by a specialist herbivore despite poor larval survival due to high saponin content. PLoS One. 9:113. e95766. DOI: 10.1371/journal.pone.0095766.

Chaieb, I. 2010. Saponins as insecticides: a review. Tunis. J. Plant Prot. 5:39-50.

Cranshaw, W.S., B.C. Kondratieff, and T. Qian. 1990. Insect associated with Quinoa, Chenopodium quinoa, in Colorado. J. Kans. Entomol. Soc. 63(1):195-199.
Cruces, L.M., Y. Callohuari, and C. Carrera. 2016. Quinua manejo integrado de plagas. Estrategias en el cultivo de la quinua para fortalecer el sistema agroalimentario en la zona andina. Organización de las Naciones Unidas para la Alimentación y la Agricultura. 198 pp.

De Geyter, E., E. Lambert, D. Geelen, and G. Smagghe. 2007. Novel advances with plant saponins as natural insecticides to control pest insects. Pest Technology. 1:96-105.

Dutcheshen, J. 2004. Method for protecting plants from bacterial diseases. Unit. States Patent. 6:743-752.

Faizal, A., and D. Geelen. 2013. Saponins and their role in biological processes in plants. Phytochem. Rev. 12:877-893. DOI: 10.1007/s11101-013-9322-4.

FAO and CIRAD. 2015. State of the Art Report of Quinoa in the World in 2013, by D. Bazile, D. Bertero, and C. Nieto, eds. Rome.

Flores, Y., C. Díaz, F. Garay, O. Colque, O. Sterner, and G.R. Almanza. 2005. Oleanane-type triterpenes and derivatives from seed coat of Bolivian Chenopodium quinoa genotype "Salar". Rev. Bol. Quím. 22:71-77.

Gómez-Caravaca, A.M., G. Iafelice, A. Lavini, C. Pulvento, M.F. Caboni, and E. Marconi. 2012. 
Phenolic compounds and saponins in quinoa samples (Chenopodium quinoa Willd.) grown under different saline and nonsaline irrigation regimens. J. Agric. Food Chem. 60(18):4620 4627. DOI:10.1021/jf3002125

Bengtsson, M.V., J.R. Hockenhull, T. Elgaard, B.K.K. Nielsen, M. Damsø. 2007. A natural product having a fungus inhibiting effect on specific fungal pathogens and a growth promoting effect for improving plant production, Google Patents, EP 1867230 A3. http://www.google. co.in/patents/EP1867230A2?cl=en (accessed 25 Jun. 2019).

Jarvis, D.E., Y.S. Ho, D.J. Lightfoot, S.M. Schmöckel, B. Li, T.J. Borm, H. Ohyanagi, K. Mineta, C.T. Michell, N. Saber, et al. 2017. The genome of Chenopodium quinoa. Nature. 542:307-312. DOI: 10.1038/nature21370.

Kuljanabhagavad, T., and M. Wink. 2009. Biological activities and chemistry of saponins from Chenopodium quinoa Willd. Phytochem. Rev. 8:473-490. DOI: 10.1007/s11101-009-9121-0.

Kuljanabhagavad, T., P. Thongphasuk, W. Chamulitrat, and M. Wink. 2008. Triterpene saponins from Chenopodium quinoa Willd. Phytochemistry. 69:1919-1926. DOI: 10.1016/j.phytochem.2008.03.001.

Latorre, B. 2018. Compendio de las enfermedades de las plantas. Ediciones UC, Santiago, Chile. $704 \mathrm{p}$.

Lozano, M., E. Ticona, C. Carrasco, Y. Flores, and G. Almanza. 2012. Cuantificación de saponinas en residuos de quinoa real Chenopodium quinoa Willd. Rev. Bol. Quím. 29:128-135.

Madl, T., H. Sterk, and M. Mittelbach. 2006. Tandem mass spectrometric analysis of a complex triterpene saponin mixture of Chenopodium quinoa. J. Am. Soc. Mass Spectrom. 17:795-806. doi:10.1016/j.jasms.2006.02.013.

Mastebroek, H.D., H. Limburg, T. Gilles, and H.J.P. Marvin. 2000. Occurrence of sapogenins in leaves and seeds of quinoa (Chenopodium quinoa Willd). J. Sci. Food Agric. 80:152-156. doi:https://doi.org/10.1002/ (SICI) 1097-0010(20000101)80:1<152::AIDJSFA503>3.0.CO;2-P.
Medina-Meza, I.G., N.A. Aluwi, S.R. Saunders, and G.M. Ganjyal. 2016. GC-MS profiling of triterpenoid saponins from 28 quinoa varieties (Chenopodium quinoa Willd.) grown in Washington State. Journal of J. Agric. Food Chem. 64:85838591. doi:10.1021/acs.jafc.6b02156.

Miranda, M., J. Delatorre-Herrera, A. Vega-Gálvez, E. Jorquera, I. Quispe-Fuentes, and E.A. Martínez. 2014. Antimicrobial potential and phytochemical content of six diverse sources of quinoa seeds (Chenopodium quinoa Willd.). Agricultural Sciences 5:1015-1024. doi:10.4236/ as.2014.511110.

Mizui, F., R. Kasai, K. Ohtani, and O. Tanaka. 1990. Saponins from bran of quinoa, Chenopodium quinoa Willd. II. Chem. Pharm. Bull. 38:375-377.

Nielsen, J.K., T. Nagao, H. Okabe, and T. Shinoda. 2010. Resistance in the plant, Barbarea vulgaris, and counter-adaptations in flea beetles mediated by saponins. J. Chem. Ecol. 36:277-285. doi:10.1007/s10886-010-9758-6.

Nozzolillo, C., J.T. Arnason, F. Campos, N. Donskov, and M. Jurzysta. 1997. Alfalfa leaf saponins and insect resistance. J. Chem. Ecol. 23:995-1002. doi:10.1023/B:JOEC.0000006384.60488.94.

Osbourn, A.E. 1996. Preformed antimicrobial compounds and plant defense against fungal attack. Plant Cell. 8:1821-1831. doi:10.1105/ tpc.8.10.1821.

Reichert, R.D., J.T. Tatarynovich, and R.T. Tyler. 1986. Abrasive dehulling of quinoa (Chenopodium quinoa): effect on saponin content as determined by an adapted hemolytic assay. Cereal Chem. 63:471-475.

Risi, C.J., and N.W. Galwey NW. 1984. The Chenopodium grains of the Andes: Inca crops for modern agriculture. Advances in Applied Biology. 10:145-216.

Risi, C.J., and N.W. Galwey NW. 1991. Genotype $\mathrm{x}$ environment interaction in the Andean grain crop quinoa (Chenopodium quinoa) in temperate environments. Plant Breed. 107:141-147. doi:10.1111/j.1439-0523.1991.tb00542.x.

Ruiz, K.B., B. Khakimov, S.B. Engelsen, S. Bak, S. Biondi, and S.E. Jacobsen. 2017. Quinoa seed 
coats as an expanding and sustainable source of bioactive compounds: An investigation of genotypic diversity in saponin profiles. Ind. Crops Prod. 104:156-163. doi:10.1016/j.indcrop.2017.04.007.

San Martin, R., K. Ndjoko, and K. Hostettmann. 2008. Novel molluscicide against Pomacea canaliculata based on quinoa (Chenopodium quinoa) saponins. Crop Prot. 27:310-319. doi:10.1016/j. cropro.2007.03.015.

Shorey, H.H., and R.L. Hale. 1965. Mass-Rearing of the larvae of nine Noctuid species on a simple artificial medium. J. Econ. Entomol. 58:522-524. doi:10.1093/jee/58.3.522.

Singh, B., and A. Kaur. 2018. Control of insect pests in crop plants and stored food grains using plant saponins: a review. J. Food Sci. Technol. 87:93101. doi:10.1016/j.lwt.2017.08.077.

Sparg, S.G., M.E. Light, and J. van Staden. 2004. Biological activities and distribution of plant saponins.
J. Ethnopharmacol. 94:219-243. doi:10.1016/j. jep.2004.05.016.

Stuardo, M., and R. San Martin. 2008. Antifungal properties of quinoa (Chenopodium quinoa Willd) alkali treated saponins against Botrytis cinerea. Ind. Crops Prod. 27(3):296-302. doi:10.1016/j.indcrop.2007.11.003.

Sylwia, G., L. Bogumil, and O. Wieslaw. 2006. Effect of low and high-saponin lines of alfalfa on pea aphid. J. Insect Physiol. 52:737-743. doi:10.1016/j.jinsphys.2006.04.001.

Woldemichael, G.M., and M. Wink. 2001. Identification and biological activities of triterpenoid saponins from Chenopodium quinoa. J. Agric. Food Chem. 49:2327-2332. doi:10.1021/jf0013499.

Yábar, E., E. Gianoli, and E.R. Echegaray. 2002. Insect pests and natural enemies in two varieties of quinoa (Chenopodium quinoa) at Cusco, Peru. J. Appl. Ent. 126:275-280. doi:10.1046/j.14390418.2002.00664.x. 